\title{
Influence of pH of Different Adhesive Systems on the Polymerization of a Chemically Cured Composite Resin
}

\author{
Eduardo Batista FRANCO ${ }^{1}$ \\ Lawrence Gonzaga LOPES ${ }^{2}$ \\ Paulo Henrique Perlatti D'ALPINO ${ }^{1}$ \\ José Carlos PEREIRA ${ }^{1}$ \\ ${ }^{1}$ Department of Operative Dentistry, Endodontics and Dental Materials, Faculty of Dentistry of Bauru, \\ University of São Paulo, Bauru, SP, Brazil \\ ${ }^{2}$ Department of Operative Dentistry, Catholic University of Brasilia (UCB), DF, Brazil
}

\begin{abstract}
The purpose of this study was to investigate the effect of $\mathrm{pH}$ of different adhesive systems on the polymerization of a chemically cured composite resin (Adaptic - AD), by means of tensile bond strength testing. The adhesive systems tested were: ARM, Prime \& Bond 2.1 (PB), Scotchbond Multi Purpose (SMP) and Single Bond (SB). Bond strength at the resin/adhesive system/resin interface was assessed. Five groups $(n=5)$ were formed, according to following configuration: G1: AD/ARM/AD; G2: AD/PB/AD; G3: AD/SMP/AD; G4: $\mathrm{AD} / \mathrm{SB} / \mathrm{AD} ; \mathrm{G} 5$ : $\mathrm{AD} / \mathrm{AD}$ (no adhesive). A two-mold stainless steel matrix with a cone-shaped opening (1-mm-thick; $4 \mathrm{~mm}$ in diameter) was used to obtain resin discs. AD resin was inserted into the first mold, left-self curing and an adhesive layer was applied onto resin surface and light-cured. The second mold was assembled over the first and was filled with the resin. After 10 min, this setting was loaded in tension in a universal testing machine running at a crosshead speed of $0.5 \mathrm{~mm} / \mathrm{min}$. Data were submitted to one-way ANOVA and Tukey’s test $(\mathrm{p}<0.05)$. Bond strength means (kgf) were: G1: $15.23 \pm 4.1$; G2: $0.00 \pm 0.0$; G3: $16.96 \pm 2.4$; G4: $10.08 \pm 2.7$; G5: 15.44 \pm 0.9 . There were statistically significant differences ( $\mathrm{p}<0.05$ ) between G2-G1; G2-G3; G2-G4; G4-G1; G4-G3. The systems with the lowest $\mathrm{pHs}$ ( $\mathrm{PB}$ and $\mathrm{SB}$ ) yielded the lowest bond strength. The findings of this in vitro study demostrates that the $\mathrm{pH}$ of adhesive systems influences the polymerization and bond strength of chemically cured resin materials. The low $\mathrm{pH}$ simplified adhesive systems showed distinct degrees of incompatibility with the chemically cured resin, when compared to the conventional adhesive systems.
\end{abstract}

Key Words: adhesive systems, pH, chemically cured resin, tensile bond strength.

\section{INTRODUCTION}

The remarkable evolution of contemporary dentin adhesive systems was aimed at the simplification of clinical steps. There are currently several types of adhesives that can be used in association with different resin restorative systems.

Conventional (three-step) and simplified adhesive systems are currently available. The bonding protocol of three-step systems requires acid-etching of enamel and dentin surfaces separately, application of a primer, which contains hydrophilic resin (HEMA) and solvents (ethanol, acetone or water) to etched dentin and subsequent application of an adhesive containing resin monomers (BIS-GMA and UDMA) to both enamel and dentin.

The simplified adhesive systems, on the other hand, have the primer and the bonding agent together in a single bottle and are a combination of hydrophilic and acidic monomers, acidic molecules, diluent monomers, photoinitiators and solvents (1-3). The single-bottle and the self-etching primers or all-in-one adhesive systems are more acidic because of their self-priming and/ or self-etching abilities (4-6). Considering that the adhesive layer does not completely polymerize in contact with oxygen and on account that in single-bottle and

Correspondence: Prof. Dr. Eduardo B. Franco, Departamento de Dentística, Endodontia e Materiais Dentários, Faculdade de Odontologia de Bauru, USP, Al. Dr. Octávio Pinheiro Brisola 9-75, 17012-901 Bauru, SP, Brasil. Tel: +55-14-3235-8484. Fax: +55-14-3235-8325. e-mail: ebfranco@fob.usp.br 
self-etching primers the adhesive layer contains acidic monomers that will be in direct contact with the composite resin layer $(4,7,8)$, it has been speculated that simplified adhesive systems could interfere with the polymerization of resin restorative materials, depending on their curing mode (i.e., chemical cure, light cure or dual cure).

Sanares et al. (4) reported that there is an inverse relation between the acidity of single-bottle adhesives and the microtensile bond strength of chemically cured composites. These results were attributed to the acidbase reaction between acidic monomers in the oxygeninhibited layer and the tertiary amines from the chemically cured composites, which is responsible, together with the benzoyl peroxide, for the polymerization process (9). Thus, the degree of polymerization of this superficial layer can be reduced resulting in low bond strength $(4,7,8)$.

The use of adhesive systems with acidic monomers in association with chemically cured and dualcured materials has been debated and investigated by both manufacturers and researchers. It has been discussed whether the use of simplified adhesive systems in the bonding protocol could negatively affect the clinical success of procedures involving the use of chemically cured resin materials, such as placement of chemically cured resin at the gingival wall of posterior composite restorations, luting indirect restorations and root canal posts with dual-cured cement.

The purpose of this in vitro study was to assess the influence of the $\mathrm{pH}$ of different adhesive systems on the polymerization of a chemically cured composite resin, by means of tensile bond strength testing.

\section{MATERIAL AND METHODS}

The tested materials with their compositions, specifications and manufacturers are shown in Table 1.

Tensile bond strength at the interface chemically cured resin/adhesive system/chemically cured resin was assessed. Five groups $(n=5)$ were formed, according to following configuration:

\section{G1: Adaptic/ARM/Adaptic}

G2: Adaptic/Prime \& Bond 2.1/Adaptic

G3: Adaptic/Scotchbond Multi Purpose/Adaptic

G4: Adaptic/Single Bond/Adaptic

G5: Adaptic/Adaptic (cohesive strength)

Table 1. Tested materials.

\begin{tabular}{|c|c|c|c|c|}
\hline Materials & Manufacturer & Type & Batch & Composition \\
\hline Adaptic & $\begin{array}{l}\text { Dentsply Ind. Com. Ltda. } \\
\text { Petrópolis, RJ, Brazil }\end{array}$ & Composite resin & 56357 & $\begin{array}{l}\text { Quartz, silica, } \\
\text { dimethacrylates, stabilizer, } \\
\text { pigments and tertiary amine } \\
\text { (base); quartz, silica, } \\
\text { dimethacrylates, stabilizer, } \\
\text { pigments and with benzoyl } \\
\text { peroxide (catalytic) }\end{array}$ \\
\hline ARM & $\begin{array}{l}\text { Dentsply Ind. Com. Ltda. } \\
\text { Petrópolis, RJ, Brazil }\end{array}$ & Conventional adhesive system & 65948 & $\begin{array}{l}\text { Dimethacrylates, stabilizers, } \\
\text { benzoyl peroxide (catalytic) } \\
\text { and tertiary amine (base) }\end{array}$ \\
\hline Prime \& Bond 2.1 & $\begin{array}{l}\text { Dentsply Ind. Com. Ltda. } \\
\text { Petrópolis, RJ, Brazil }\end{array}$ & Simplified adhesive system & 56039 & $\begin{array}{l}\text { PENTA, UDMA, } \\
\text { photoinitiators, stabilizers, } \\
\text { cetylamine hydrofluoride and } \\
\text { acetone }\end{array}$ \\
\hline Scotchbond Multi Purpose & $\begin{array}{l}3 \mathrm{M} \\
\text { St. Paul, MN, USA }\end{array}$ & Conventional adhesive system & 25081 & $\begin{array}{l}\text { Bis-GMA, HEMA, } \\
\text { photoinitiators }\end{array}$ \\
\hline Single Bond & $\begin{array}{l}3 \mathrm{M} \\
\text { St. Paul, MN, USA }\end{array}$ & Simplified adhesive system & 1105 & $\begin{array}{l}\text { Bis-GMA, polyalkenoic acid, } \\
\text { dimethacrylates, HEMA, } \\
\text { photoinitiators, ethanol and } \\
\text { water }\end{array}$ \\
\hline
\end{tabular}


For specimen preparation, a two-mold stainless steel matrix with a cone-shaped hole measuring $4 \mathrm{~mm}$ in diameter and $1 \mathrm{~mm}$ in thickness was used to obtain two composite resin discs. In groups G1, G2, G3 and $\mathrm{G} 4$, the composite resin was proportioned according to the manufacturer's instructions, inserted into the first mold using bulk filling technique and left self-curing for $10 \mathrm{~min}$. Thereafter, an adhesive layer was applied onto composite resin surface and light-cured for $20 \mathrm{~s}$. The second mold was assembled over the first mold, and another composite resin increment was inserted into the matrix and left self-curing for $10 \mathrm{~min}$ to provide a resin/adhesive/resin setting (Fig. 1). In group 5, only composite resin increments were placed into the two molds, and the resin discs were obtained without application an intermediary adhesive layer between them. This group was settled to evaluate the composite resin cohesive strength.

Ten minutes after composite resin polymerization, the molds with the resin/adhesive/resin setting were adjusted to a custom device that was connected to a load cell. This configuration was then attached to the base of a universal testing machine (Kratos, São Paulo, SP, Brazil) (Fig. 2). The hourglass-shaped specimens were loaded in tension running at a crosshead speed of $0.5 \mathrm{~mm} / \mathrm{min}$ until fracture.

The acidity $(\mathrm{pH})$ of the adhesive systems was measured. Three $\mathrm{mL}$ of each adhesive was dispensed

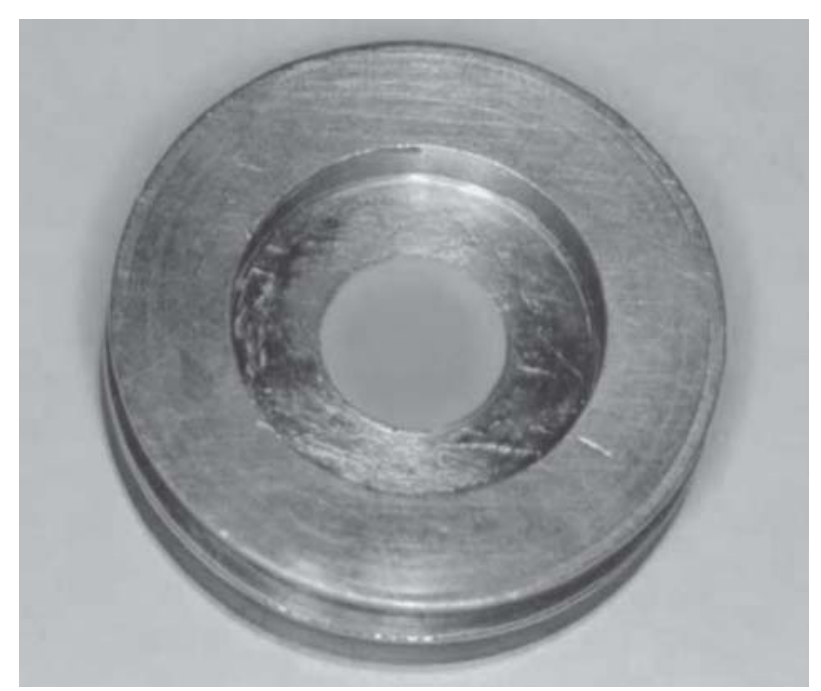

Figure 1. Stainless steel matrix with the test specimen. Upper view of the composite resin/adhesive system/composite resin setting. into clean glass vials and stirred for $30 \mathrm{~s}$. The $\mathrm{pH}$ values were measured at room temperature $\left(22-25^{\circ} \mathrm{C}\right)$ using a digital pH meter (Micronal B371, São Paulo, SP, Brazil).

Data were submitted to one-way ANOVA for statistical analysis and multiple comparisons were done using Tukey’s tests at 0.05 significance level.

\section{RESULTS}

The tensile bond strength means (kgf) and standard deviations for the experimental groups, as well as the $\mathrm{pH}$ of each adhesive system are given in Table 2.

Statistically significant differences $(\mathrm{p}<0.05)$ were detected between the following groups: G2-G1; G2G3; G2-G4; G4-G1; G4-G3.

The lowest bond strength means were recorded for the simplified adhesive systems Prime \& Bond 2.1 and Single Bond, which had the lowest pHs among the tested materials (2.1 and 4.6, respectively).

\section{DISCUSSION}

When simplified adhesive systems are used together with resin materials containing elements responsible for the chemical curing reaction, there will be an interaction between the residual acidic monomers from the adhesive oxygen-inhibited layer and the binary peroxide-amine system, which interferes with the bonding process $(4,5,8,10,11)$. In this study, three-step and simplified adhesive systems were used in association
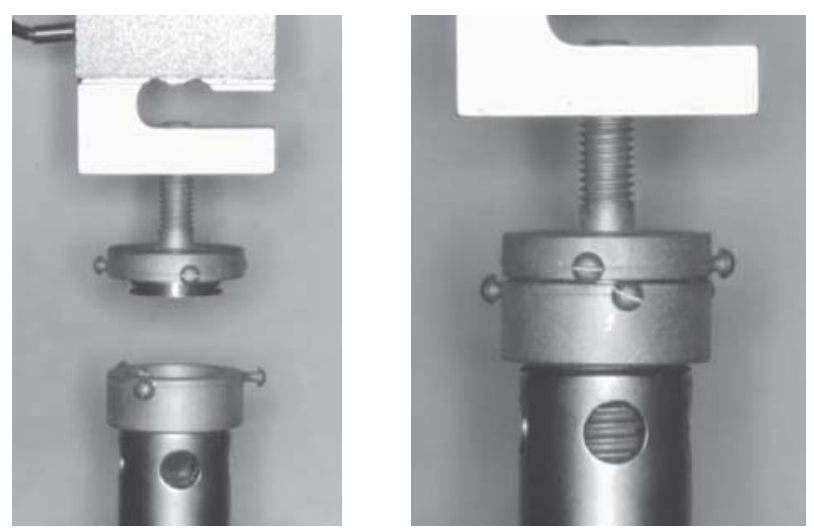

Figure 2. Tensile bond strength testing. Left - Stainless steel matrix with the test specimen attached to the custom device fixed to the load cell. Right - Specimen attached to the base of the universal testing machine. 
Table 2. Means \pm SD of the tensile bond strength (TSB) (kgf) for the experimental groups and $\mathrm{pH}$ of the tested adhesive systems.

\begin{tabular}{lccccc}
\hline \multicolumn{5}{c}{ Groups/Adhesive systems } \\
\cline { 2 - 6 } & G1 & G2 & G3 & G4 & G5 \\
& ARM & Prime \& Bond 2.1 & Scotchbond Multi Purpose & Single Bond & No adhesive \\
\hline TBS & $15.23 \pm 4.1^{\mathrm{a}}$ & $0.00 \pm 0.0^{\mathrm{b}}$ & $16.96 \pm 2.4^{\mathrm{a}}$ & $10.08 \pm 2.7^{\mathrm{c}}$ & $15.44 \pm 0.9^{\mathrm{a}}$ \\
$\mathrm{pH}$ & 6.4 & 2.1 & 6.2 & 4.6 & - \\
\hline
\end{tabular}

Different letters indicate statistically significant difference $(\mathrm{p}<0.05)$.

with a chemically cured composite resin. The results showed that both simplified adhesive systems (Prime \& Bond 2.1 and Single Bond) had significantly lower bond strengths than the conventional adhesive systems (ARM and Scotchbond Multi Purpose). In fact, Prime \& Bond 2.1 yielded totally negligible bond strengths.

Prime \& Bond 2.1 and Single Bond also had the lowest $\mathrm{pH}$ values (2.1 and 4.6, respectively) among the tested adhesive systems, which is possibly related to the presence of acidic monomers in their compositions leading to low bond strength means. These findings are in agreement with those of Tay et al. (8) and Yamauchi (12), who stated that, in their studies, the residual acidic monomers cured poorly in the presence of the peroxide/ amine system because of the acid-base interaction between acidic monomers and tertiary amine. This reaction leads to competition with the common redox reaction between benzoyl peroxide and tertiary amine, which is possible due to the slower polymerization rate in chemically cured composites $(6,8)$. Therefore, the results of the present study could hypothetically be attributed to a correlation between the acidity of the simplified adhesive systems and their bond strengths to chemically cured composite resins materials.

Questions have arisen from the association of acidic adhesive systems and light-cured or dual-cured resins because these materials possess tertiary amine in their composition.

A previous investigation (13) using the same methodology as that of the present study, in which a dual-cured resin cement (Enforce; Dentsply) was used with several adhesive systems (including Prime \& Bond), found no incompatibility between the tested materials. Nevertheless, Tay et al. (8) showed that there is an exponential decrease in tensile bond strengths with time when a light-cured composite is in prolonged contact with acidic adhesives before light activation. Likewise, Schiltz et al. (7), using a dual-cured resin cement (Duo-Link, Bisco), reported that bond strength was inversely proportional to the interval between the placement of the cement and its photo-activation. They stated that the reaction between acidic monomers and tertiary amine occurs slowly.

Therefore, it may be speculated that the use of acidic adhesive systems in association with chemically cured resin materials could compromise the success rate of some clinical procedures, such as placement of a chemically cured resin layer at the gingival wall of cavities restored according to the posterior composite resin technique, luting indirect restorations and root canal posts with dual-cured cements. Based on the findings of this study, it seems advisable to avoid the combination of acidic adhesives (single-bottle, selfetching primers or all-in-one systems) and chemically cured materials. Moreover, the use of products from the same manufacturer is also recommended.

The findings of this in vitro study suggest that the $\mathrm{pH}$ of adhesive systems influence the polymerization and bond strength of chemically cured resin materials. The tested simplified adhesive systems, which had the lowest $\mathrm{pH}$, were incompatible with the chemically cured resin, while the conventional three-step adhesive systems did not affect the composite resin bond strength negatively.

\section{RESUMO}

O objetivo desse estudo foi investigar o efeito do $\mathrm{pH}$ de diferentes sistemas adesivos na polimerização de uma resina composta quimicamente ativada (Adaptic - AD), por meio do teste de resistência à tração. Os sistemas adesivos utilizados foram: 
ARM, Prime \& Bond 2.1 (PB), Scotchbond Multi Purpose (SMP) e Single Bond (SB). Cinco grupos $(n=5)$ foram formados: G1: AD/ARM/AD; G2: AD/PB/AD; G3: AD/SMP/AD; G4: AD/ SB/AD; G5: AD/AD (sem interposição de adesivo). Uma matriz de aço inoxidável com abertura central no formato de cone (1 mm de espessura; 4 mm de diâmetro), foi utilizada para obter dois discos de resina composta. A resina $\mathrm{AD}$ foi inserida em uma primeira metade da matriz em incremento único. Após a polimerização da resina, uma camada de adesivo foi aplicada na superfície de união e foto-ativada. A segunda metade da matriz foi justaposta à primeira e preenchida com a resina. Após $10 \mathrm{~min}$, o conjunto foi adaptado em uma máquina universal de ensaios para determinar a resistência à tração, com velocidade de 0,5 $\mathrm{mm} / \mathrm{min}$. Os dados foram submetidos a ANOVA e teste de Tukey $(\mathrm{p}<0,05)$. As médias (kgf) obtidas em cada grupo foram: $\mathrm{G1}$ : 15,23 \pm 4,1; G2: $0,00 \pm$ 0,0; G3: 16,96 \pm 2,4; G4: 10,08 \pm 2,7; G5: $15,44 \pm 0,9$. Houve diferença estatisticamente significante $(p<0.05)$ entre os grupos G2-G1; G2-G3; G2-G4; G4-G1; G4G3. Os sistemas com pHs mais baixos (PB e SB) apresentaram as menores médias de resistência à tração. Os achados desse estudo in vitro sugerem que o $\mathrm{pH}$ dos sistemas adesivos influencia na polimerização e na resistência adesiva de materiais resinosos quimicamente ativados. Os sistemas adesivos simplificados testados, com valores de $\mathrm{pH}$ mais baixos, mostraram graus distintos de incompatibilidade com a resina quimicamente ativada, quando comparados aos sistemas adesivos convencionais.

\section{REFERENCES}

1. Carvalho RM. Adesivos dentinários. Fundamentos para aplicação clínica. Rev Dent Restauradora 1998;1:62-96.

2. Perdigão J, Lopes M. Dentin bonding. Questions for the new millennium. J Adhes Dent 1999;1:191-209.

3. Tay FR, Carvalho RM, Yiu CKY, King NM, Zhang Y, Agee K, Bouillaguet S, Pashley DH. Mechanical disruption of dentin collagen fibrils during resin-dentin bond testing. J Adhes Dent 2000;2:175-192.

4. Sanares AME, Itthagarun A, King NM, Tay FR, Pashley DH. Adverse surface interactions between one-bottle light-cured adhesives and chemical-cured composites. Dent Mater 2001;17:542-546.

5. Tay FR, Pashley DH, Yiu CKY, Sanares AME, Wei SHY. Factors contributing to the incompatibility between simplified-step adhesives and chemically-cured or dual-cured composites. Part I. Single-step self-etching adhesive. J Adhes Dent 2003;5:2740.

6. Tay FR, Sano H, Carvalho RM, Pashley EL, Pashley DH. An ultrastructural study of the influence of acidity of self-etching primers and smear layer thickness on bonding to intact dentin. J Adhes Dent 2000;2:83-98.

7. Schiltz MY, Cincione F, Derijk W, Suh BI. Bond strength of single bottle adhesives to self-cured composites on dentin. J Dent Res 2000;79:374 (Abstract).

8. Tay FR, King NM, Suh BI, Pashley DH. Effect of delayed activation of light-cured resin composites on bonding of allin-one adhesives. J Adhes Dent 2001;3:207-225.

9. Cook WD, Standish PM. Polymerization kinetics of resinbased restorative materials. J Biomed Mater Res 1983;17:275282.

10. King NM, Tay FR, Suh BI, Pashley DH. Compromised bonding of all-in-one adhesives upon delayed activation of light-cured composites. J Dent Res 2001;80:639 (Abstract).

11. Rueggeberg FA, Margeson DH. The effect of oxygen inhibition on an unfilled/filled composite system. J Dent Res 1990;69:1652-1658.

12. Yamauchi J. Study of dental adhesive containing phosphoric acid methacrylate monomer. Japan J Dent Mater 1986;5:144154.

13. Franco EB, Lopes LG, D’Alpino PHP, Pereira JC, Mondelli RFL, Navarro MFL. Evaluation of compatibility between different types of adhesives and dual-cured resin cement. J Adhes Dent 2002;4:1-5. 